\title{
Diazonium-based impedimetric aptasensor for the rapid label-free detection of Salmonella typhimurium in food sample
}

Zahra Bagheryan, Jahan-Bakhsh Raoof, Mohsen Golabi, Anthony Turner and Valerio Beni

\author{
Linköping University Post Print
}

\section{Tweet}

N.B.: When citing this work, cite the original article.

Original Publication:

Zahra Bagheryan, Jahan-Bakhsh Raoof, Mohsen Golabi, Anthony Turner and Valerio Beni, Diazonium-based impedimetric aptasensor for the rapid label-free detection of Salmonella typhimurium in food sample, 2016, Biosensors \& bioelectronics, (80), 566-573.

http://dx.doi.org/10.1016/j.bios.2016.02.024

Copyright: Elsevier

http://www.elsevier.com/

Postprint available at: Linköping University Electronic Press

http://urn.kb.se/resolve?urn=urn:nbn:se:liu:diva-127249 
1

$6{ }^{1}$ Biosensors and Bioelectronics Centre, Department of Physics, Chemistry and Biology (IFM),

7 Linkoping University, 58183, Linkoping (Sweden)

$8 \quad{ }^{2}$ Eletroanalytical Chemistry Research Laboratory, Department of Analytical Chemistry, Faculty

9 of Chemistry, University of Mazandaran, Babolsar, Iran

11 Corresponding author:

12

Dr. Valerio Beni Ph.D.

13

e-mail: valerio.beni@acreo.se

14 
27 Fast and accurate detection of microorganisms is of key importance in clinical analysis and in

28 food and water quality monitoring. S. typhimurium is responsible for about a third of all cases of

29 foodborne diseases and consequently, its fast detection is of great importance for ensuring the 30 safety of foodstuffs.

31 We report the development of a label-free impedimetric aptamer-based biosensor for $S$. 32 typhimurium detection. The aptamer biosensor was fabricated by grafting a diazonium33 supporting layer onto screen-printed carbon electrodes (SPEs), via electrochemical or chemical 34 approaches, followed by chemical immobilisation of aminated-aptamer. FTIR-ATR, contact 35 angle and electrochemical measurements were used to monitor the fabrication process. Results 36 showed that electrochemical immobilisation of the diazonium-grafting layer allowed the 37 formation of a denser aptamer layer, which resulted in higher sensitivity. The developed 38 aptamer-biosensor responded linearly, on a logarithm scale, over the concentration range $1 \times 10^{1}$ 39 to $1 \times 10^{8} \mathrm{CFU} \mathrm{mL} \mathrm{m}^{-1}$, with a limit of quantification (LOQ) of $1 \times 10^{1} \mathrm{CFU} \mathrm{mL} \mathrm{m}^{-1}$ and a limit of 40 detection (LOD) of $6 \mathrm{CFU} \mathrm{mL}^{-1}$. Selectivity studies showed that the aptamer biosensor could 41 discriminate S. typhimurium from 6 other model bacteria strains. Finally, recovery studies 42 demonstrated its suitability for the detection of S. typhimurium in spiked $\left(1 \times 10^{2}, 1 \times 10^{4}\right.$ and 1 $43 \times 10^{6} \mathrm{CFU} \mathrm{mL}^{-1}$ ) apple juice samples.

\section{Keywords:}

46 Diazonium grafting, aptamer, S. typhimurium, label-free detection, electrochemical impedance 47 spectroscopy, food analysis 


\section{Introduction}

Salmonella Typhimurium (S. Typhimurium), the second most common serotype (after Salmonella

51 enteritidis) found in humans, is responsible, worldwide, for about a third of all cases of

52 foodborne diseases (Gupta et al. 2003). Salmonellosis is an increasingly important health

53 concern and is usually associated with the consumption of Salmonella-contaminated foods,

54 mainly of animal origin, including beef (Wells et al. 2001), pork (Malorny and Hoorfar 2005),

55 poultry (Carli et al. 2001) and turkeys (Nayak et al. 2003). However, non-animal products, such

56 as fresh vegetables and fruits, fruit juices and spices, have also been associated with infections.

57 Fruit juices are becoming increasingly relevant vehicles for Salmonella infection (Jain et al.

58 2009; Sivapalasingam et al. 2004; Vojdani et al. 2008).

59 Currently, the detection of Salmonella in food still relies on culture-based approaches or on the combination of these with biochemical (immuno) assays. Despite being very accurate and having

61 the ability discriminate between live and dead cells, these assays are time-consuming, tedious, 62 impractical (Lazcka et al. 2007) and, more importantly, are not suitable for on-site and real-time 63 applications (June et al. 1995).

64 Recently, DNA microarrays (Gardner et al. 2010) have been shown to offer new opportunities 65 for pathogen detection in a multiplex format at reasonable cost and speed (2-3 h to get results). 66 Real time PCR (RT-PCR) has consequently, rapidly become a common analytical techniques for 67 pathogen detection (Jain et al. 2009; Postollec et al. 2011). Nevertheless, PCR based analytical 68 approaches are still far from being applicable to real-time or on-site analysis, since they still 69 require well-equipped laboratories. 
Biosensors have been extensively explored for pathogen detection with the aim of developing

71 new tools for fast, low cost, real-time and on-site detection or screening. The simplest format for

72 microbial monitoring is based on the detection of generic biomarkers, shared by most of the

73 microorganism, such as ATP. ATP bioluminescence assays have been used, for the last three

74 decades, for the rapid monitoring of surface microbial loading in the food industry and hospitals

75 (Driscoll et al. 2007).

76 Assays based on the affinity between a ligand (antibodies, bacteriophages or lectins) and

77 receptors onto the microbial cell surface have also been widely investigated (Karmali 2009).

78 Antibody-based immunosensors have been the most explored approach in the development of

79 portable pathogen detection (Chung et al. 2014; Seymour et al. 2015). However, the limited

80 stability of antibodies is a major drawback in their widespread utilisation.

81 Aptamers are short single-stranded oligonucleotides that can bind, with high affinity, to a wide

82 range of targets (Jayasena 1999) and are usually selected through an in vitro process using an

83 exponential enrichment process (SELEX) (Chiu and Huang 2009). They have been explored as

84 possible replacements for antibodies in bioaffinity assays and their potential for delivering real-

85 time detection of microbial cells, from a variety of samples types, has been demonstrated

86 (Dwivedi et al. 2010; Hamula et al. 2011; Joshi et al. 2009; Kaerkkaeinen et al. 2011; Ozalp et

87 al. 2013; Torres-Chavolla and Alocilja 2009a, b; Wu et al. 2012). Among the different

88 transduction approaches used for aptasensing, electrochemistry is of particular significance

89 because of its advantages, such as high sensitivity, selectivity, simple instrumentation and low

90 endogenetic background (Labib et al. 2012; Zelada-Guillen et al. 2009).

91 Stable and controllable immobilisation of biorecognition elements onto transducing surfaces is of 92 great importance in the development of electrochemical biosensors. Currently the most 
commonly adopted approach takes advantage of the strong affinity between SH groups and gold surfaces to produce self-assembled monolayer (SAM)-based platforms (Brasil de Oliveira Marques et al. 2009; Peterlinz et al. 1997). SAMs have found widespread application, but still present significant limitations: the surface modification is time consuming and its stability can be affected by different factors such as electrical potentials (Lockett and Smith 2009), UV irradiation (Shewchuk and McDermott 2009) and high temperatures (Civit et al. 2010). Some of these limitations have been overcome by the use of diazonium chemistry (Belanger and Pinson 2011; Galli 1988), which offers several advantages in terms of speed, simplicity and stability (Civit et al. 2010; Torréns et al. 2015b). Diazonium-grafted surfaces have found widespread application in different areas such as sensors (Corgier et al. 2005b, 2007) and catalysis (Bourdillon et al. 1992b). Diazonium grafted layers have a long-term stability under atmospheric conditions (Allongue et al. 1997) and are minimally affected by ultrasound treatments (Adenier et al. 2006), high temperatures (Civit et al. 2010) and electric potentials (Haque and Kim 2011; Piper et al. 2011; Revenga-Parra et al. 2012). Diazonium molecules modified with various functional groups have been introduced onto electrodes for immobilisation of biomolecules such as enzymes (Bourdillon et al. 1992a; Liu et al. 2007; Polsky et al. 2007; Radi et al. 2006), proteins (Corgier et al. 2005a) and antibodies (Corgier et al. 2005a; Ho et al. 2010) for biosensing application. To the best of our knowledge, there are just a few reports on the use of this chemistry for immobilisation of DNA (Ruffien et al. 2003; Shabani et al. 2006; Torrens et al. 2015a; Torrens et al. 2015b) and these were only for hybidisation assays.

Herein, we report on the development of a label-free impedimetric biosensor for Salmonella enterocs serover. Typhimurium (S. typhimurium) detection. More specifically screen-printed electrodes (SPEs) were modified with diazonium salt through electrochemical and Zn-mediated 
116 chemical grafting and the properties, of the fabricated aptasensors based on these were compared

117 in terms of surface density of the aptamer layer and sensitivity. The analytical performances of

118 the sensors were then further investigated and the detection of S. typhimurium in spiked apple

119 juice sample was demonstrated.

120 The aptasensor developed via electrochemical grafting had higher sensitivity and responded

121 linearly over the concentration range $1 \times 10^{1}$ to $1 \times 10^{8} \mathrm{CFU} \mathrm{mL}^{-1}$. It also had high selectivity in 122 the presence of other pathogens and was suitable for the detection of S. typhimurium in spiked 123 apple juice samples.

\section{EXPERIMENTAL}

127 2.1. Reagents

128 All reagents were of analytical grade and used as received. N-ethyl-N'-(3-dimethylaminopropyl) 129 carbodiimide hydrochloride (EDC), 4-aminbenzoic acid, tetrafluoroboric acid solution, zinc 130 powder, sodium nitrite $99.5 \%$, potassium ferricyanide (III) and potassium ferrocyanide (II), 131 were purchased from Sigma-Aldrich (Sweden).

132 All pathogenic strains used in this work were acquired from the Culture Collection (the three E. 133 coli strains), University of Gothenburg, Sweden or donated from the Linköping University 134 Hospital (Salmonella typhimurium, Entrobacter aerogenes, Citrobacter freundii and Kelebsiella 135 pneumonia).

136 The aminated DNA aptamer against Salmonella was purchased from biomers.net (Germany).

137 The sequence of the aptamer ( 45 in the original work), selected against S. typhimurium outer 138 membrane proteins (OMPs), was obtained from the work of Joshi et al. (Joshi et al. 2009): 
139

140

141

142

143

144

145

146

147

148

149

150

151

152

153

154

155

156

157

158

159

160

161

$5 '-\mathrm{NH}_{2}-\mathrm{ttt}$ ggt cet tgt ctt atg tcc aga atg cga gga aag tct ata gca gag gag atg tgt gaa ccg agt aaa ttt ctc cta ctg gga tag gtg gat tat-3'

\subsection{Pathogen preparation:}

The cultivation of S. Typhimurium, and of the other pathogenic strains used in this work, was performed in nutrient broth (NB) medium at $37^{\circ} \mathrm{C}$ by shaking at $170 \mathrm{rpm}$ for $16 \mathrm{~h}$. The cultures containing bacteria were centrifuged at $3765 \mathrm{~g}$ for $5 \mathrm{~min}\left(25^{\circ} \mathrm{C}\right)$ and washed with PBS $(0.1 \mathrm{M}$, $\mathrm{pH}$ 7.4) three times. After washing, the pellet was suspended in $15 \mathrm{~mL}$ of PBS and used as the original S. typhimurium stock solution; all other concentrations were made by diluting this in PBS. The pathogen concentration in the stock solution was estimated by measuring the optical density at $600 \mathrm{~nm}$. Correlation between optical density and bacterial concentration $\left(\mathrm{CFU} \mathrm{mL} \mathrm{m}^{-1}\right)$ was determined, at the beginning of this work, by the standard plate count method for each bacterial strain.

\subsection{Instrumentation}

Voltammetric experiments were carried out using an Ivium Stat. XR electrochemical analyser coupled with dedicated software (Ivium, Eindhoven, Netherlands). The impedance spectra were recorded within the frequency range of $100 \mathrm{kHz}$ to $0.05 \mathrm{~Hz}$ in $5 \mathrm{mM} \mathrm{K} 3\left[\mathrm{Fe}(\mathrm{CN})_{6}\right] / \mathrm{K}_{4}\left[\mathrm{Fe}(\mathrm{CN})_{6}\right]$ (1:1) mixture in $10 \mathrm{mM}$ PBS $(\mathrm{pH} \mathrm{7.4)}$ at a bias potential of $0 \mathrm{mV}$ vs OCP potential. The amplitude of the applied sine wave potential was $5 \mathrm{mV}$. The Nyquist plots obtained were fitted to an equivalent circuit to extract the value of charge-transfer resistance $\left(R_{c t}\right)$. Chronocoulometry was used for the determination of aptamer surface coverage. The following parameters were used to perform the chronocoulometric measurements: pulse period $=500 \mathrm{~ms}$, pulse width $=500 \mathrm{mV}$. 
162 Screen-printed electrodes (SPEs) consisted of a carbon working electrode (4 mm in diameter); a 163 carbon counter electrode and a silver pseudo-reference electrode printed onto a ceramic 164 substrate; these were purchased from Dropsens, Spain (Manufacturer code DRP-110). All the 165 experiments were carried out at room temperature $\left(21^{\circ} \mathrm{C}\right)$. ATR-FTIR measurements were 166 obtained using a PIKE MIRacle ATR accessory with a diamond prism in a Vertex 70 167 spectrometer (Bruker) using a DTGS detector at room temperature under continuous purging of $168 \mathrm{~N}_{2}$. IR spectra were obtained at $4 \mathrm{~cm}^{-1}$ resolution and 32 scans between 4000 and $800 \mathrm{~cm}^{-1}$. The 169 static water contact angles of the films were measured using the sessile drop technique with fresh 170 Milli Q water (18.2 M $\Omega$ ) with the aid of a CAM200 Optical Contact Angle Meter (KVS 171 Instrument, Finland).

2.3 Synthesis of 4-Amino benzoic acid tetrafluoroborate $(\mathrm{ACOOH})$

4-Aminobenzoic acid tetrafluoroborate was synthesised by dissolving $1.16 \mathrm{gr}(8.5 \mathrm{mmol})$ of 4 176 aminobenzoic acid in $9 \mathrm{ml}$ of $50 \% \mathrm{w} / \mathrm{w}$ aqueous tetrafluoroboric acid solution. The solution was 177 heated until the 4-aminbenzoic acid completely dissolved and was then cooled in an ice water 178 bath. Following dissolution of the amine, a cold solution of $0.73 \mathrm{~g}(10.5 \mathrm{mmol})$ of sodium nitrite 179 in $2 \mathrm{ml} \mathrm{MilliQ} \mathrm{water} \mathrm{was} \mathrm{added} \mathrm{dropwise} \mathrm{to} \mathrm{the} \mathrm{reaction} \mathrm{mixture} \mathrm{with} \mathrm{stirring.} \mathrm{The} \mathrm{slurry} \mathrm{was}$ 180 cooled in an ice bath to favor crystallisation. The resulting white solid was collected on a 181 Buchner funnel, washed with ice water and cold ether, dried under vacuum and finally stored at $1824{ }^{\circ} \mathrm{C}$ in the dark (Baranton and Bélanger 2005; Dunker et al. 1936; Polsky et al. 2008). The 183 presence of the diazonium functional group in the synthesised compound was confirmed by IR 184 spectra. 
187 Electrochemical grafting: The electrochemical grafting was performed using a solution of $5 \mathrm{mM}$ 188 of $\mathrm{ACOOH}$ in $0.5 \mathrm{M}$ cold sulphuric acid. A drop of diazonium solution $(50 \mu \mathrm{L})$ was placed onto 189 the SPE and then 10 cyclic voltammograms were recorded over the range from 0 to $-1 \mathrm{~V}$ at 0.2 $190 \mathrm{~V} / \mathrm{s}$ (Ho et al. 2010).

191 Zn-mediated grafting: To modify the electrodes through Zn-mediated chemical grafting, a 192 mixture of $20 \mu \mathrm{L}$ of $5 \mathrm{mM}$ of $\mathrm{ACOOH}$ in $0.5 \mathrm{M}$ sulphuric acid containing an excess of $\mathrm{Zn}$ 193 powder was stirred for 5 min under a stream of $\mathrm{N}_{2}$, added to the electrode surface and left to react 194 for 5 min (Torréns et al. 2015b).

195

2.5 Preparation and characterisation of aptasensors:

197 Following modification with the diazonium-grafting layer the electrodes were sonicated in water 198 for $1 \mathrm{~min}$, in order to remove weakly bounded molecules, and dried under a stream of $\mathrm{N}_{2}$. The 199 carboxyl groups present in the grafted diazonium layer were activated with 4:1 molar ratio of 200 EDC (200 mM): NHS $(50 \mathrm{mM})$ in water for $30 \mathrm{~min}$. After rinsing with water and draying under 201 nitrogen stream, a drop of $4 \mu \mathrm{M}$ aminated-DNA aptamer (in $10 \mathrm{mM}$ PBS buffer $\mathrm{pH}$ 7.4) was 202 placed on the activated surface for $1 \mathrm{~h}$. The unreacted carboxylate groups were then deactivated 203 with $1 \mathrm{mM}$ ethanolamine $(\mathrm{pH}$ 8) for $30 \mathrm{~min}$. Finally, the modified electrodes were washed in 204 PBS solution for 30 min to remove unspecifically chemisorbed aptamers. The ability of the 205 developed aptasensors to detect $S$. typhimurium was assessed by testing them with solution 206 containing different concentrations of the bacterias. The overall process is summarised in 207 Scheme 1. 
210 Detection of bacteria was performed accordingly to the following protocol: aptasensors were

211 incubated for $30 \mathrm{~min}$ (Labib et al. 2012) in the $10 \mathrm{mM}$ PBS buffer (pH 7.4) solution containing

212 the bacteria or in the spiked apple juice sample; this step was performed by immersing the 213 aptasensors in $10 \mathrm{~mL}$ of the tested solution. Following a 15 min wash in $10 \mathrm{mM}$ PBS buffer (pH

214 7.4) electrodes were immersed in the $10 \mathrm{mM}$ PBS buffer ( $\mathrm{pH} 7.4$ ) containing the $5 \mathrm{mM}$

$215 \mathrm{~K}_{3}\left[\mathrm{Fe}(\mathrm{CN})_{6}\right] / \mathrm{K}_{4}\left[\mathrm{Fe}(\mathrm{CN})_{6}\right](1: 1)$ mixture where EIS spectra were recorded accordingly to protocol 216 described in section 2.3. A calibration curve was constructed by exposing the aptasensor to 217 increasing concentrations, from $10^{1}$ to $10^{8} \mathrm{CFU} \mathrm{mL} \mathrm{m}^{-1}$, of S. typhimurium. Each of the point in 218 the calibration curve, selectivity curves and in the spiked sample analysis were the average of 3 219 measurements performed using 3 individual electrodes.

\section{LOCATION OF SCHEME 1}

\subsection{FTIR spectra}

Diazonium salt was synthesised ex-situ according to the protocol described above (section 2.3)

227 and characterised by FTIR-ATR (Supplementary material, Fig S1). As can be seen from Fig. S1,

228 where the FTIR-ATR spectra of 4-aminbenzoic acid before and after diazonium formation are 229 compared, a new band appeared after diazonium formation at about $2304 \mathrm{~cm}^{-1}$. This new band 230 has been previously associated with the $(\mathrm{C}-\mathrm{N}=\mathrm{N})$ group in diazonium salt (Socrates 2001). A 231 shift in the FTIR peak for carboxylic acid from $1656 \mathrm{~cm}^{-1}$ to $1718 \mathrm{~cm}^{-1}$ has also been recorded in 232 the case of the diazonium salt; this shift can be the result of the electron acceptor properties of 233 the newly formed diazo group. 


\subsection{Electrochemical characterisation of the aptasensor}

236 Electrochemical impedance spectroscopy (EIS) measurements were used to characterise the 237 step-by-step assembly of the aptasensor. Fig. 1 shows the Nyquist plots obtained for a SPE (a), $238 \mathrm{ACOOH} / \mathrm{SPE}$ (b) and aptamer/ACOOH/SPE (c), via electrochemical (solid line) and Zn 239 mediated chemical grafting (dotted line). Measurements were performed using a $5.0 \mathrm{mM}$ $240\left[\mathrm{Fe}(\mathrm{CN})_{6}\right]^{3-/ 4-}$ couple $(1: 1)$ solution in $10 \mathrm{mM}$ PBS $(\mathrm{pH} 7.4)$.

\section{LOCATION FIGURE 1}

244 As can be seen from Fig. 1, the impedance dramatically increased following ACOOH grafting, 245 regardless of which approach (electrochemical or Zn-mediated) was adopted for the surface 246 modification, indicating successful grafting of the ACOOH. Increases in $\mathrm{R}_{\mathrm{ct}}$ were the result of 247 the formation of a highly packed negatively charged film on the electrodes surface that was 248 effectively blocking, via electrostatic repulsion, the diffusion of the $\left[\mathrm{Fe}(\mathrm{CN})_{6}\right]^{3-/ 4-}$ couple to the 249 sensor surface. A higher blocking effect was achieved, as expected, for the electrochemical 250 grafting; this was probably due to the higher level of immobilisation or to the formation of 251 multilayers (Kariuki and McDermott 1999). The value of $R_{c t}$ dramatically decreased after DNA 252 aptamer immobilisation (curves C of Fig. 1). This was the result of the lower density of negative 253 charges associated with: (i) the low density and the 3D structure of the bulky aptamer chain 254 (when compared to the $\mathrm{ACOOH}$ ) and (ii) the partial neutralisation of the $\mathrm{COOH}$ originally on the 255 surface due to the blocking step with ethanolamine (Hayat et al. 2012; Hayat et al. 2011). 256 Modeling of the impedance data was realised according to the Randles circuit depicted in the 
257 inset of Fig. 1. This is based on the charge transfer resistance $\left(\mathrm{R}_{\mathrm{ct}}\right)$, the constant phase element $258(\mathrm{CPE})$, the solution resistance $\left(\mathrm{R}_{\mathrm{s}}\right)$ and the Warburg impedance $(\mathrm{W})$.

3.3. Contact angle measurement:

261 The success of the assembly was also confirmed by contact angle measurement. In order to 262 record this, a drop $(10 \mu \mathrm{l})$ of fresh Milli Q water (18.2 M 2$)$ was placed onto the unmodified 263 and/or modified surfaces and five images were recorded using a CAM200 Optical Contact Angle 264 Meter. Fig. S2 summarises the average of the contact angle values obtained. Contact angle 265 decreased sequentially after diazonium salt and aptamer immobilisation, regardless of the 266 grafting process adopted. The decrease in contact angle is due to the increased hydrophilicity of 267 the surface due firstly to the introduction of the $\mathrm{COOH}$ group, and secondly to the 268 immobilisation of the DNA aptamer.

3.4 Determination of aptamer surface density:

271 Aptamer surface coverage for the two constructed aptasensors (via electrochemical and $\mathrm{Zn}$ 272 mediated chemical grafting) was obtained using the well-established $\mathrm{DNA} /\left[\mathrm{Ru}\left(\mathrm{NH}_{3}\right)_{6}\right]^{3+}$ 273 interaction and chronocoulometric measurements (Wang et al. 2010; Yu et al. 2003). It is known 274 that $\left[\mathrm{Ru}\left(\mathrm{NH}_{3}\right)_{6}\right]^{3+}$ binds to the anionic phosphate base of DNA in 1 to 3 ratio. Thereby 275 calculation of surface DNA $\left(\Gamma_{\text {DNA }}\right)$ coverage can be performed by determining the $\left[\mathrm{Ru}\left(\mathrm{NH}_{3}\right)_{6}\right]^{3+}$ 276 entrapped in DNA layer $\left(\Gamma_{0}\right)$. In Fig. 2 the typical chronocoulometric curves recorded during this 277 evaluation are presented. 
280 Measurements were recorded at the aptamer modified electrodes in the absence and presence of $28150 \mu \mathrm{M}$ of $\left[\mathrm{Ru}(\mathrm{NH} 3)_{6}\right]^{3+}$. Assuming that the double layer capacitance remains approximately 282 constant, $\mathrm{nFA}_{0}$ (Eq. 1), the charge from the reduction of absorbed redox marker, can be 283 measured by using the difference in intercepts:

$284 \mathrm{Q}=\mathrm{nFA} \Gamma_{0}$

Eq. 1

285 Where $\mathrm{n}$ is the number of electrons per molecule for reduction, $\mathrm{F}$ the Faraday constant 286 (C/equiv), A the electrode area $\left(\mathrm{cm}^{2}\right)$ and $\Gamma_{0}$ is the surface excess of adsorbed redox marker.

287 The active areas of the electrodes were determined using the simplified Randles-Sevcik 288 expression at $25^{\circ} \mathrm{C}$ by carrying out cyclic voltammetry of $5 \mathrm{mM}\left[\mathrm{Fe}(\mathrm{CN})_{6}\right]^{3-/ 4-}$ in $0.2 \mathrm{M} \mathrm{KCl}$ at 289 different scan rates. The area for carbon screen-printed electrode was calculated to be $2900.0028 \pm 0.00014 \mathrm{~cm}^{2}$ (geometric surface area $0.00125 \mathrm{~cm}^{2}$ ). As expected, the calculated active 291 area is significantly larger than the geometrical one, due to the rough morphology of the 292 electrode material.

293 The surface coverage of aptamer can be calculated from the integrated Cottrell expression at 294 time $=0$ (Eq. 2) in the absence and presence of redox marker using the relationship:

$295 \Gamma_{\mathrm{DNA}}=\Gamma_{0}(\mathrm{z} / \mathrm{m}) \mathrm{N}_{\mathrm{A}}$ Eq. 2

296 Where $\Gamma_{\text {DNA }}$ is aptamer surface density $\left(\right.$ molecule $\left./ \mathrm{cm}^{2}\right), \mathrm{z}$ is the charge of the redox molecule, $\mathrm{m}$ 297 is the number of bases of aptamer (96) and N Avogadro's number.

298 Surface coverages of $6.25 \times 10^{13}\left(\right.$ molecule $\left./ \mathrm{cm}^{2}\right)$ for the electrochemical grafting method and of $2995.33 \times 10^{12}\left(\right.$ molecule $\left./ \mathrm{cm}^{2}\right)$, for the $\mathrm{Zn}$-mediated chemical grafting were obtained. As can be 300 seen, the aptamer surface coverage was higher in the case of electrochemical grafting method. 301 The surface coverage results obtained herein differed from those reported by Torrens et al. 
302 (Torréns et al. 2015a); in our case the surface density was higher in the electrochemical approach 303 that in the Zn-mediated method. These results could be due to the formation of a denser and 304 more easily self-organised layer, due to the small sizes of the 4-amino benzoic acid 305 tetrafluoroborate when compared to 5-bis(4-diazophenoxy)benzoic acid tetrafluoborate.

\subsection{Electrochemical detection of S. typhimurium:}

The S. typhimurium detection was performed by immersing the aptasensor in a solution of bacteria (in $10 \mathrm{mM}$ PBS pH 7.4) for 30 min (Labib et al. 2012), followed by EIS measurements. To be sure that the PBS buffer did not have any effect on the impedimetric response of the aptasensor, the response obtained for the sensor as the function of the immersion time in pure (no

312 bacteria) PBS was studied. This was performed by immersing the aptasensor in PBS solution, in 313 the presence of the $\left[\mathrm{Fe}(\mathrm{CN})_{6}\right]^{3 / 4}$ couple, and recording EIS measurements every 15 min. Fig. S3 314 shows that the $R_{\mathrm{ct}}$ was increasing over the first $30 \mathrm{~min}$; this increase was probably due to the 3D 315 reorganisation of the aptamer on the sensor surface. After this initial period of change, the $R_{c t}$ became constant. To minimise this effect the aptasensors were pre-conditioned in PBS solution,

317 for $30 \mathrm{~min}$, prior to bacteria detection.

318 The analytical performances of the aptasensors prepared using the two grafting approaches, were 319 compared by using them for the detection of two concentrations of S. typhimurium $\left(1 \times 10^{2}\right.$ and 1 $320 \times 10^{8} \mathrm{CFU} \mathrm{mL} \mathrm{m}^{-1}$ ). Fig 3A shows that the responses recorded from the electrochemically grafted 321 aptasensor were consistently higher than those obtained by the chemical grafting. These results 322 are most likely related to the higher surface density of the aptamer layer (see section 3.4). 
326 In the light of this result, full calibration, selectivity and recovery experiments were only

327 performed using the aptasensor fabricated by the electrochemical grafting approach.

328 The aptasensors were calibrated using various concentrations of S. typhimurium (from $1 \times 10^{1}$ to

$3291 \times 10^{8} \mathrm{CFU} \mathrm{mL} \mathrm{mL}^{-1}$ ) and following the protocol described in Section 2.6. Capture of $S$.

330 typhimurium onto the aptasensor surface resulted in an increase of the $\mathrm{R}_{\mathrm{ct}}$; this can be explained

331 either by the physical blocking effect of the captured bacteria or by the electrostatic repulsion

332 between the negatively charged bacterial cells and the $\left[\mathrm{Fe}(\mathrm{CN})_{6}\right]^{3-/ 4-}$ redox probe. As it can be

333 seen from Fig. $3 \mathrm{~B}, \mathrm{R}_{\mathrm{ct}}$ values increased linearly with the logarithmic concentration of the

334 bacteria in the range from $1 \times 10^{1}$ to $1 \times 10^{8} \mathrm{CFU} \mathrm{mL}^{-1}$. The LOD (as 3 times the standard

335 deviation of the blank, no pathogen, experiment) was determined to be $6 \mathrm{CFU} \mathrm{mL} \mathrm{m}^{-1}$. It was also

336 found that the aptasensor could be easily regenerated by dissociating the aptamers from the

337 bacteria in $2 \mathrm{M} \mathrm{NaCl}$ for $30 \mathrm{~min}$, as demonstrated by impedance and staining experiments (Fig 338 S4).

339 Reproducibility of the aptasensor was calculated over the full range of concentration; this 340 resulted in an average $\mathrm{RSD}$ of $15 \%$ ( $\mathrm{n}=3$ for each of the 8 concentrations used).

341 The ability of the aptasensor to distinguish between target bacteria and other bacteria strains was 342 also investigated by EIS experiments. In this set of experiment solutions containing $10^{6} \mathrm{CFU}$ $343 \mathrm{~mL}^{-1}$ of different bacteria were used. $10^{6} \mathrm{CFU} \mathrm{mL}^{-1}$ was chosen because it has been demonstrate 344 to provide relevant information on specific interaction between bacteria surfaces (Golabi et al., 345 2016). 
349 Fig. 4 shows that very small responses were recorded with the other investigated bacteria (three 350 different kinds of Escherichia coli (CCUG 3274, CCUG53375, and CCUG10979), Entrobacter 351 aerogenes, Citrobacter freundii and Kelebsiella pneumonia), thus indicating that the aptasensor 352 is highly specific for S. Typhimurium.

$354 \quad 3.6$ Recovery studies and Salmonella determination in apple juice

355 To demonstrate the applicability of the proposed aptasensor to real samples analysis, recovery 356 studies on spiked apple juice samples were performed. The responses of the aptasensor where 357 then fitted to the calibration curve $(Y=0.116 X+0.0107)$ shown in Fig. $3 B$, in order to calculate 358 the concentration of recovered S. typhimurium from the sample. Reproducibility of the detection 359 was calculated for both spiked concentration $(n=3)$; this resulted in an average RSD of $18.6 \%$.

\section{LOCATION FIGURE 5}

Fig. 5 shows the response of the aptasensor in the absence and presence of different 364 concentration of spiked bacteria in apple juice. The apple juice had no significant effect on the aptasensor response, while on addition of different concentration of S. typhimurium. $\left(1 \times 10^{2}, 1 \times\right.$

$36610^{4}$ and $1 \times 10^{6} \mathrm{CFU} \mathrm{mL}^{-1}$ ) the $\mathrm{R}_{\mathrm{ct}}$ increased significantly. As can be seen in the inset of Fig. 5, 367 the aptasensor achieved good recovery illustrating its applicability for real sample analysis.

\section{CONCLUSION}


371 We report the development of a label-free, impedimetric biosensor for S. typhimurium detection.

372 Two different approaches, based on electrochemical and Zn-mediated chemical grafting, have

373 been explored and compared for the fabrication of an aptasensor, .

374 Electrochemical grafting of 4-amino benzoic acid tetrafluoroborate facilitated the formation of a

375 denser (ca. 2 times) aptamer biorecognition layer. The electrochemically prepared aptasensor 376 was more sensitive for detection at both low $\left(1 \times 10^{2} \mathrm{CFU} \mathrm{mL} \mathrm{mL}^{-1}\right)$ and high $\left(1 \times 10^{8} \mathrm{CFU} \mathrm{mL}^{-1}\right)$ 377 concentrations of S. typhimurium, compared to the Zn-mediated chemically grafted devices. The 378 aptasensor responded linearly to the logarithm of the S. typhimurium concentration over the 379 range $1 \times 10^{1}$ to $1 \times 10^{8} \mathrm{CFU} \mathrm{mL} \mathrm{m}^{-1}$ and was highly selective for $S$. typhimurium with a LOQ of $38010^{1} \mathrm{CFU} \mathrm{mL} \mathrm{m}^{-1}$ and a LOD of $6 \mathrm{CFU} \mathrm{mL} \mathrm{m}^{-1}$. Finally, recovery experiments demonstrated that the 381 sensor was suitable for the detection of three different concentrations of $S$. typhimurium $\left(1 \times 10^{2}\right.$, $3821 \times 10^{4}$ and $1 \times 10^{6} \mathrm{CFU} \mathrm{mL}^{-1}$ ) in apple juice. Comparison (Table $1 \mathrm{~S}$ ) of the performance of the 383 reported aptasensor with those of relevant label-less electrochemical (impedimetric or 384 potentiometric) aptasensors, indicates that the developed aptasensor has an LOD comparable to 385 existing state of the art, but with a larger dynamic range. More significantly and more 386 importantly and in contrast to previous work (Sheikhzadeh et al, 2016; Ma et al., 2014), the 387 aptasensor worked in undiluted real sample.

391 ZB acknowledges the Ministry of Science Research and Technology of Iran (www.msrt.ir) to 392 support her study visit at Linköping University. The authors acknowledge Vetenskapsrådet 
(Pathoscreen project; Swedish Research Link; ref.-ID: D0675001) for supporting the development of the aptasensor and Dr. V. C. Ozalp for helping with the aptamer identification.

\section{REFERENCE:}

Adenier, A., Barré, N., Cabet-Deliry, E., Chaussé, A., Griveau, S., Mercier, F., Pinson, J., Vautrin-Ul, C., 2006. Surf. Sci. 600(21), 4801-4812.

Allongue, P., Delamar, M., Desbat, B., Fagebaume, O., Hitmi, R., Pinson, J., Savéant, J.-M., 1997. J. Am. Chem. Soc. 119(1), 201-207.

Baranton, S., Bélanger, D., 2005. J. Phys. Chem. B 109(51), 24401-24410.

Belanger, D., Pinson, J., 2011. Chem. Soc. Rev. 40(7), 3995-4048.

Bourdillon, C., Delamar, M., Demaille, C., Hitmi, R., Moiroux, J., Pinson, J., 1992a. J. Electroanal. Chem. 336(1-2), 113-123.

Bourdillon, C., Delamar, M., Demaille, C., Hitmi, R., Moiroux, J., Pinson, J., 1992b. J. Electroanal. Chem. 336(1), 113-123.

Brasil de Oliveira Marques, P.R., Lermo, A., Campoy, S., Yamanaka, H., Barbé, J., Alegret, S., Pividori, M.I., 2009. Anal. Chem. 81(4), 1332-1339.

Carli, K.T., Unal, C.B., Caner, V., Eyigor, A., 2001. J. Clin. Microbiol. 39(5), 1871-1876.

Chiu, T.-C., Huang, C.-C., 2009. Sensors 9(12), 10356.

Chung, B., Shin, G.W., Choi, W., Joo, J., Jeon, S., Jung, G.Y., 2014. Electrophoresis 35(23), 3283-3289.

Civit, L., Fragoso, A., O'Sullivan, C.K., 2010. Electrochem. Commun. 12(8), 1045-1048.

Corgier, B.P., Marquette, C.A., Blum, L.J., 2005a. J. Am. Chem. Soc. 127(51), 18328-18332.

Corgier, B.P., Marquette, C.A., Blum, L.J., 2005b. J. Am. Chem. Soc. 127(51), 18328-18332.

Corgier, B.P., Marquette, C.A., Blum, L.J., 2007. Biosens. Bioelectron. 22(7), 1522-1526.

Driscoll, M., Ramsay, C., Watkin, J., 2007. improved sensitivity method for rapid hygiene monitoring using atp bioluminescence. pp. 79-82.

Dunker, M.F.W., Starkey, E.B., Jenkins, G.L., 1936. J. Am. Chem. Soc. 58(11), 2308-2309.

Dwivedi, H.P., Smiley, R.D., Jaykus, L.-A., 2010. Appl. Microbiol. Biotechnol. 87(6), 23232334.

Galli, C., 1988. Chem. Rev. 88(5), 765-792.

Gardner, S., Jaing, C., McLoughlin, K., Slezak, T., 2010. BMC Genomics 11(1), 1-21.

Golabi, M., Turner APF., Jager EWH., 2016. Sensors and Actuators B 222, 839-848.

Gupta, A., Fontana, J., Crowe, C., Bolstorff, B., Stout, A., Duyne, S.V., Hoekstra, M.P., Whichard, J.M., Barrett, T.J., Group, t.N.A.R.M.S.P.W., 2003. J. Infect. Dis 188(11), 1707-1716. Hamula, C.L.A., Zhang, H., Li, F., Wang, Z., Le, X.C., Li, X.-F., 2011. Trac.Trend. in Anal. Chem. 30(10), 1587-1597.

Haque, A.-M.J., Kim, K., 2011. Chem. Commun. 47(24), 6855-6857.

Hayat, A., Barthelmebs, L., Marty, J.-L., 2012. Sens. Actuators B: Chem. 171-172, 810-815.

Hayat, A., Barthelmebs, L., Sassolas, A., Marty, J.-L., 2011. Talanta 85(1), 513-518. 
Ho, J.-a.A., Hsu, W.-L., Liao, W.-C., Chiu, J.-K., Chen, M.-L., Chang, H.-C., Li, C.-C., 2010. Biosens. Bioelectron. 26(3), 1021-1027.

Jain, S., Bidol, S.A., Austin, J.L., Berl, E., Elson, F., Williams, M.L., Deasy, M., Moll, M.E., Rea, V., Vojdani, J.D., Yu, P.A., Hoekstra, R.M., Braden, C.R., Lynch, M.F., 2009. Clin. Infect. Dis. 48(8), 1065-1071.

Jayasena, S.D., 1999. Clin. Chem. 45(9), 1628-1650.

Joshi, R., Janagama, H., Dwivedi, H.P., Senthil Kumar, T.M.A., Jaykus, L.-A., Schefers, J., Sreevatsan, S., 2009. Mol. Cell. Probes. 23(1), 20-28.

June, G.A., Sherrod, P.S., Hammack, T.S., Amaguana, R.M., Andrews, W.H., 1995. J AOAC Int 78(2), 375-380.

Kaerkkaeinen, R.M., Drasbek, M.R., McDowall, I., Smith, C.J., Young, N.W.G., Bonwick, G.A., 2011. Int. J. Food Sci. Technol. 46(3), 445-454.

Kariuki, J.K., McDermott, M.T., 1999. Langmuir 15(19), 6534-6540.

Karmali, M.A., 2009. Kidney Int 75, S4-S7.

Labib, M., Zamay, A.S., Kolovskaya, O.S., Reshetneva, I.T., Zamay, G.S., Kibbee, R.J., Sattar, S.A., Zamay, T.N., Berezovski, M.V., 2012. Anal. Chem. 84(21), 8966-8969.

Lazcka, O., Campo, F.J.D., Muñoz, F.X., 2007. Biosens. Bioelectron. 22(7), 1205-1217.

Liu, G., Böcking, T., Gooding, J.J., 2007. J. Electroanal. Chem. 600(2), 335-344.

Lockett, M.R., Smith, L.M., 2009. Langmuir 25(6), 3340-3343.

Ma, X., Jiang, Y., Jia, F., Yu, Y., Chen, J., Wang, Z., 2014. J. Microbiol. Methods 98, 94-98.

Malorny, B., Hoorfar, J., 2005. J. Clin. Microbiol. 43(7), 3033-3037.

Nayak, R., Kenney, P.B., Keswani, J., Ritz, C., 2003. Br. Poult. Sci. 44(2), 192-202.

Ozalp, V.C., Bilecen, K., Kavruk, M., Oktem, H.A., 2013. Future Microbiol. 8(3), 387-401.

Peterlinz, K.A., Georgiadis, R.M., Herne, T.M., Tarlov, M.J., 1997. J. Am. Chem. Soc. 119(14), 3401-3402.

Piper, D.J.E., Barbante, G.J., Brack, N., Pigram, P.J., Hogan, C.F., 2011. Langmuir 27(1), 474480.

Polsky, R., Harper, J.C., Dirk, S.M., Arango, D.C., Wheeler, D.R., Brozik, S.M., 2007. Langmuir 23(2), 364-366.

Polsky, R., Harper, J.C., Wheeler, D.R., Dirk, S.M., Arango, D.C., Brozik, S.M., 2008. Biosens. Bioelectron. 23(6), 757-764.

Postollec, F., Falentin, H., Pavan, S., Combrisson, J., Sohier, D., 2011. Food Microbiol. 28(5), 848-861.

Radi, A.E., Montornes, J.M., O'Sullivan, C.K., 2006. J. Electroanal. Chem. 587(1), 140-147.

Revenga-Parra, M., Gómez-Anquela, C., García-Mendiola, T., Gonzalez, E., Pariente, F., Lorenzo, E., 2012. Anal. Chim. Acta 747, 84-91.

Ruffien, A., Dequaire, M., Brossier, P., 2003. Chem. Commun.(7), 912-913.

Seymour, E., Daaboul, G.G., Zhang, X., Scherr, S.M., Unlu, N.L., Connor, J.H., Unlu, M.S., 2015. Anal. Chem. 87(20), 10505-10512.

Shabani, A., Mak, A.W.H., Gerges, I., Cuccia, L.A., Lawrence, M.F., 2006. Talanta 70(3), 615623.

Sheikhzadeh, E., Chamsaz, M., Turner, A.P.F., Jager, E.W.H., Beni, V., 2016, Biosens. Bioelectron. in press. (doi:10.1016/j.bios.2016.01.057)

Shewchuk, D.M., McDermott, M.T., 2009. Langmuir 25(8), 4556-4563.

Sivapalasingam, S., Friedman, C.R., Cohen, L., Tauxe, R.V., 2004. J. Food Prot. 67(10), 23422353. 
479 Socrates, G., 2001. Infrared and Raman characteristic group frequencies : tables and charts, 3rd 480 ed. Wiley, Chichester; New York.

481 Torrens, M., Ortiz, M., Turner, A.P.F., Beni, V., O'Sullivan, C.K., 2015. Electrochem. Commun. 482 53, 6-10.

483 Torréns, M., Ortiz, M., Turner, A.P.F., Beni, V., O'Sullivan, C.K., 2015a. Electrochem. 484 Commun. 53, 6-10.

485 Torréns, M., Ortiz, M., Turner, A.P.F., Beni, V., O'Sullivan, C.K., 2015b. Chem. Eur. J. 21(2), 486 671-681.

487 Torres-Chavolla, E., Alocilja, E.C., 2009a. Biosens. Bioelectron. 24(11), 3175-3182.

488 Torres-Chavolla, E., Alocilja, E.C., 2009b. Biosens. Bioelectron. 24(11), 3175-3182.

489 Vojdani, J.D., Beuchat, L.R., Tauxe, R.V., 2008. J. Food Prot. 71(2), 356-364.

490 Wang, J., Zhang, S., Zhang, Y., 2010. Anal. Biochem. 396(2), 304-309.

491 Wells, S.J., Fedorka-Cray, P.J., Dargatz, D.A., Ferris, K., Green, A., 2001. J. Food Prot. 64(1), 349211.

493 Wu, W.-h., Li, M., Wang, Y., Ouyang, H.-X., Wang, L., Li, C.-X., Cao, Y.-c., Meng, Q.-h., Lu, 494 J.-X., 2012. Nanoscale Res. Lett. 7(1), 658-658.

495 Yu, H.-Z., Luo, C.-Y., Sankar, C.G., Sen, D., 2003. Anal. Chem. 75(15), 3902-3907.

496 Zelada-Guillen, G.A., Riu, J., Duezguen, A., Rius, F.X., 2009. Angew. Chem. Int. Ed. 48(40), $497 \quad 7334-7337$.

498

499

500

501 
504 Scheme 1. Overview of the preparation of the Salmonella aptasensor.

505 Fig. 1. Faradic complex impedance plots in $5 \mathrm{mM}\left[\mathrm{Fe}(\mathrm{CN})_{6}\right]^{3-} /\left[\mathrm{Fe}(\mathrm{CN})_{6}\right]^{4-}$ for different 506 immobilisation steps on SPEs through electrochemical (solid line) and Zn-mediated grafting 507 (dotted line): bare SPE (a), ACOOH/SPE (b) and Apt/ACOOH/SPE (c).

508 Fig. 2. Chronocoulometric response curves for modified electrodes in the absence (a) and 509 presence of $50 \times 10^{-6} \mathrm{M}$ Ruhex via electrochemical grafting in the absence (c) and presence of 510 aptamer (e), and Zn-mediated grafting in the absence (b) and presence of aptamer (d).

511 Fig. 3, (A). Bar chart of $\Delta \mathrm{R}_{\mathrm{ct}} / \mathrm{R}_{\mathrm{ct}}$ versus Log concentration of $S$. typhimurium for electrochemical 512 and Zn-mediated grafting method (B). EIS results for aptasensor incubated with different 513 concentration of $S$. typhimurium and calibration curve for $\Delta \mathrm{R}_{\mathrm{ct}} / \mathrm{R}_{\mathrm{ct}}$ versus Log concentration of $S$. 514 typhimurium (inset) in $5 \mathrm{mM}\left[\mathrm{Fe}(\mathrm{CN})_{6}\right]^{3-} /\left[\mathrm{Fe}(\mathrm{CN})_{6}\right]^{4-}$ in PBS buffer.

515 Fig. 4. Specificity of aptasensor for S. typhimurium detection.

516 Fig. 5. Curve of $\Delta \mathrm{R}_{\mathrm{ct}} / \mathrm{R}_{\mathrm{ct}}$ versus different concentration $\left(1 \times 10^{2}, 1 \times 10^{4}\right.$ and $\left.1 \times 10^{6} \mathrm{CFU} \mathrm{mL}^{-1}\right)$ 517 of S. typhimurium in apple juice and recovery results (inset) for the detection of S. typhimurium 518 from apple juice sample. 
524

525
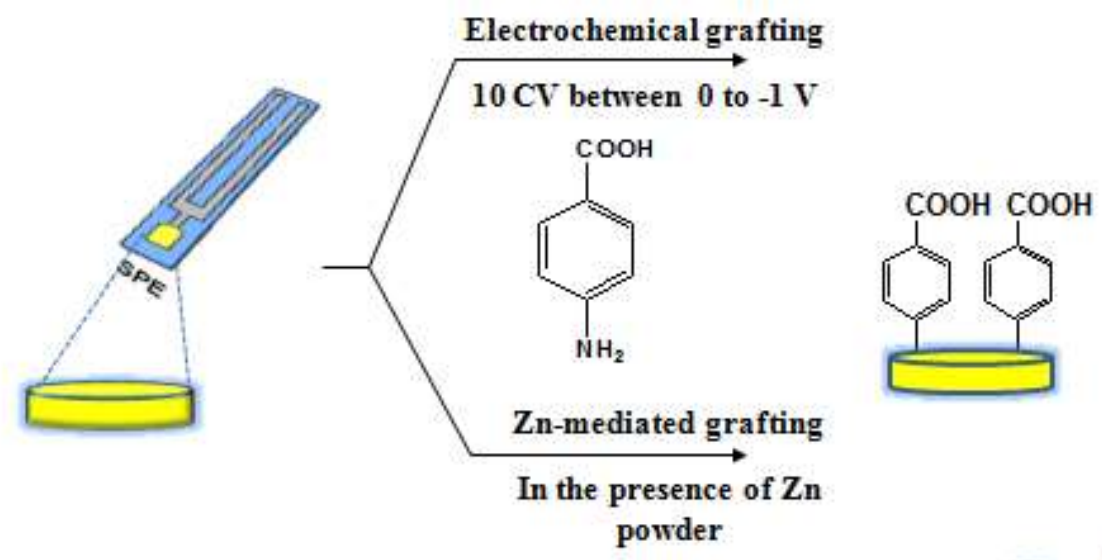

1) $\mathrm{EDC} / \mathrm{NHS}(4: 1)$

2) $\mathrm{NH}_{2}$-Aptamer

3) Ethanolamine

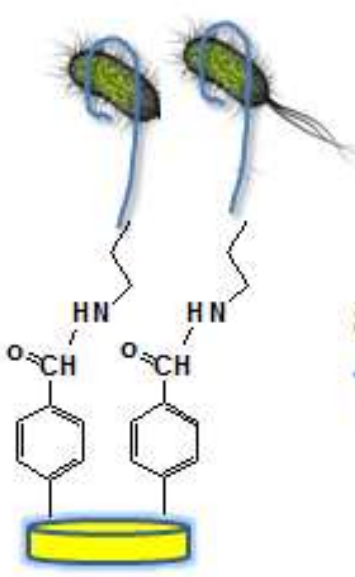

Salmonella detection
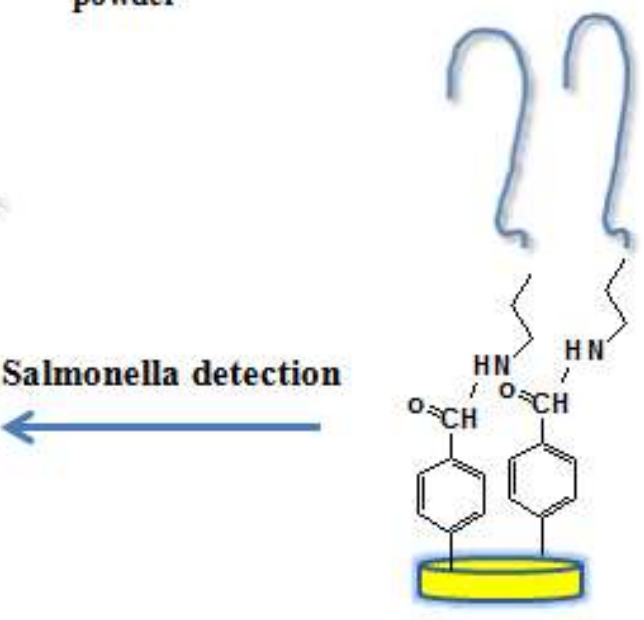


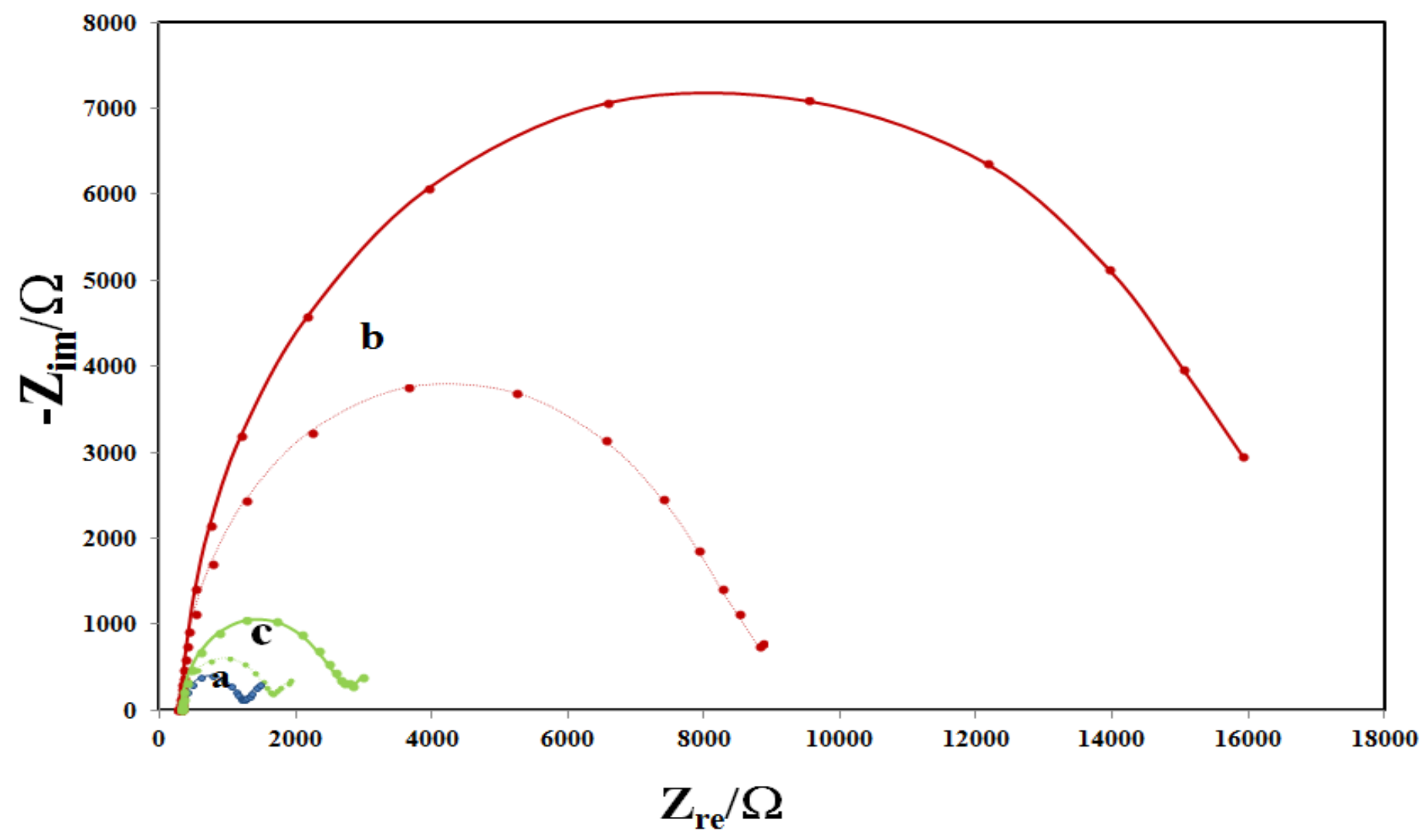

530

531

Fig. 1

532

533 


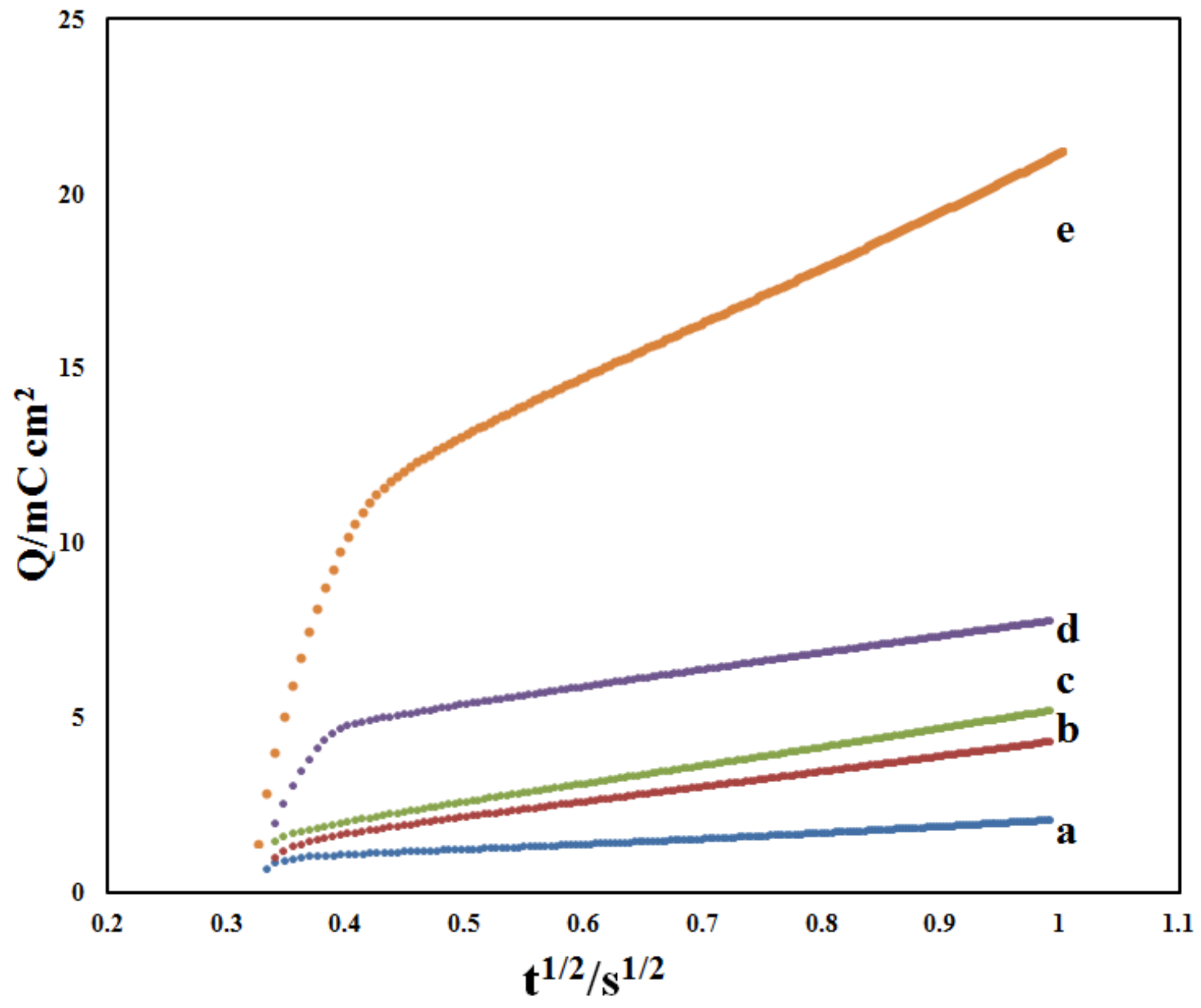

Fig. 2

537 

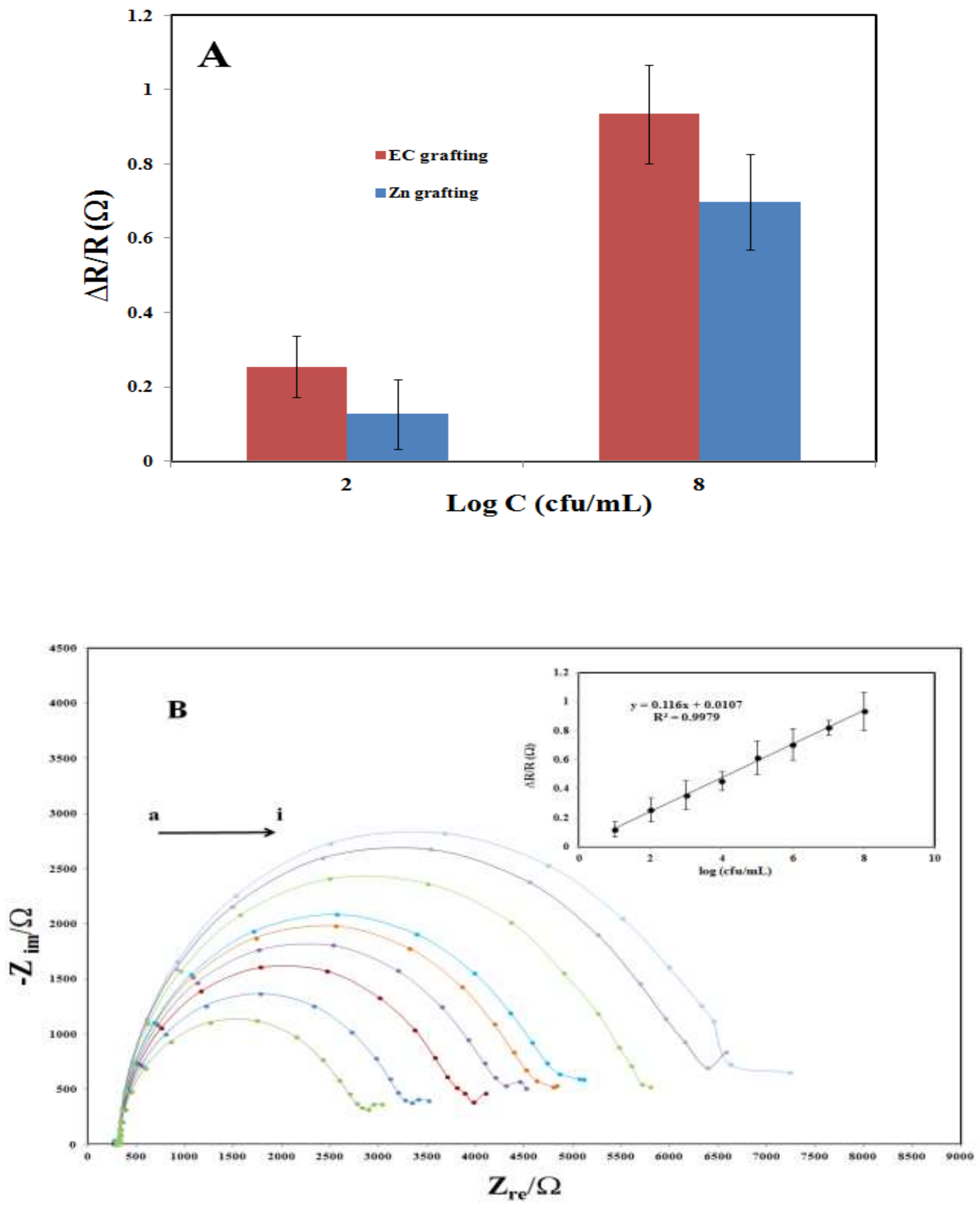

Fig. 3 


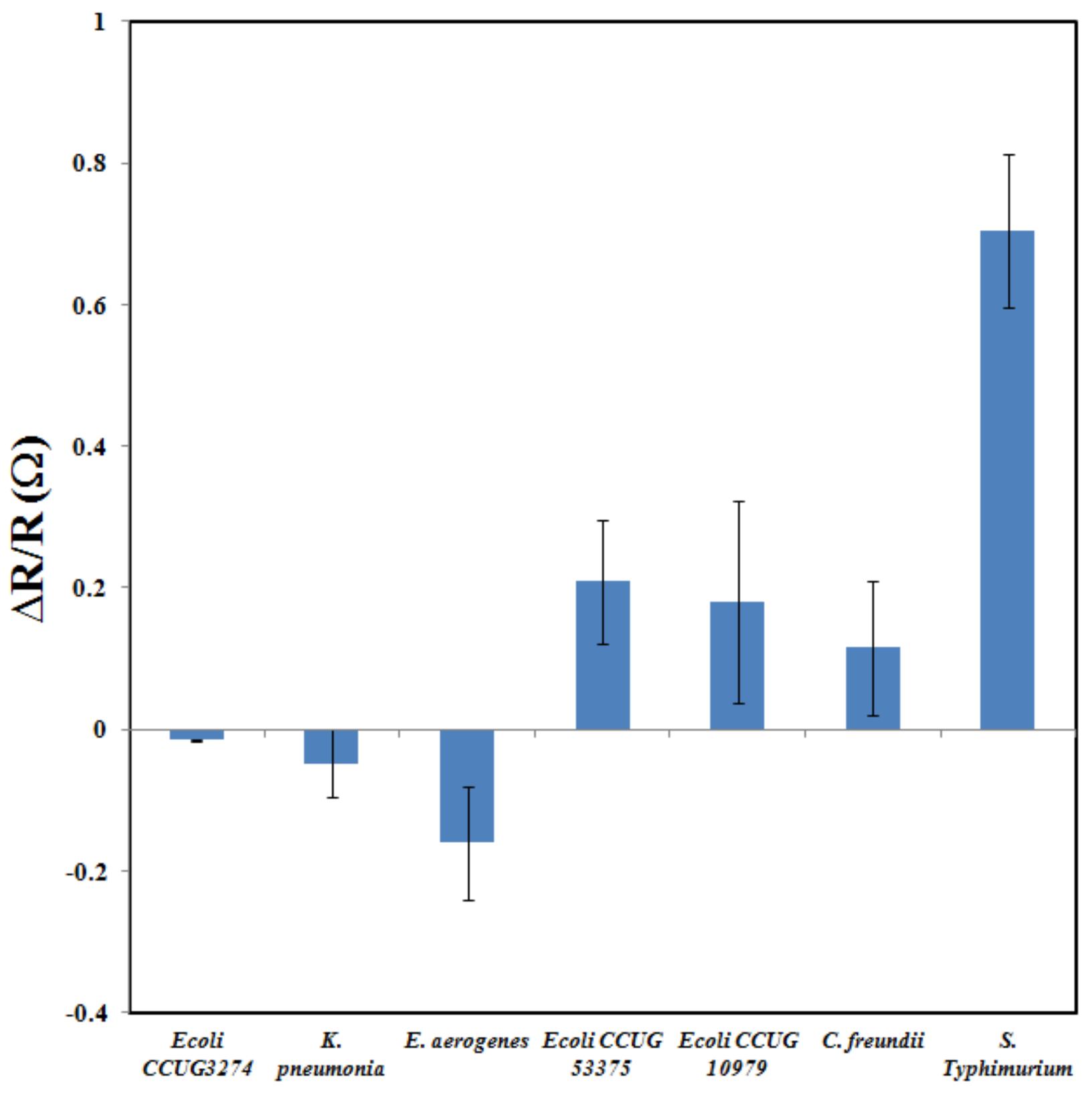

Fig. 4 


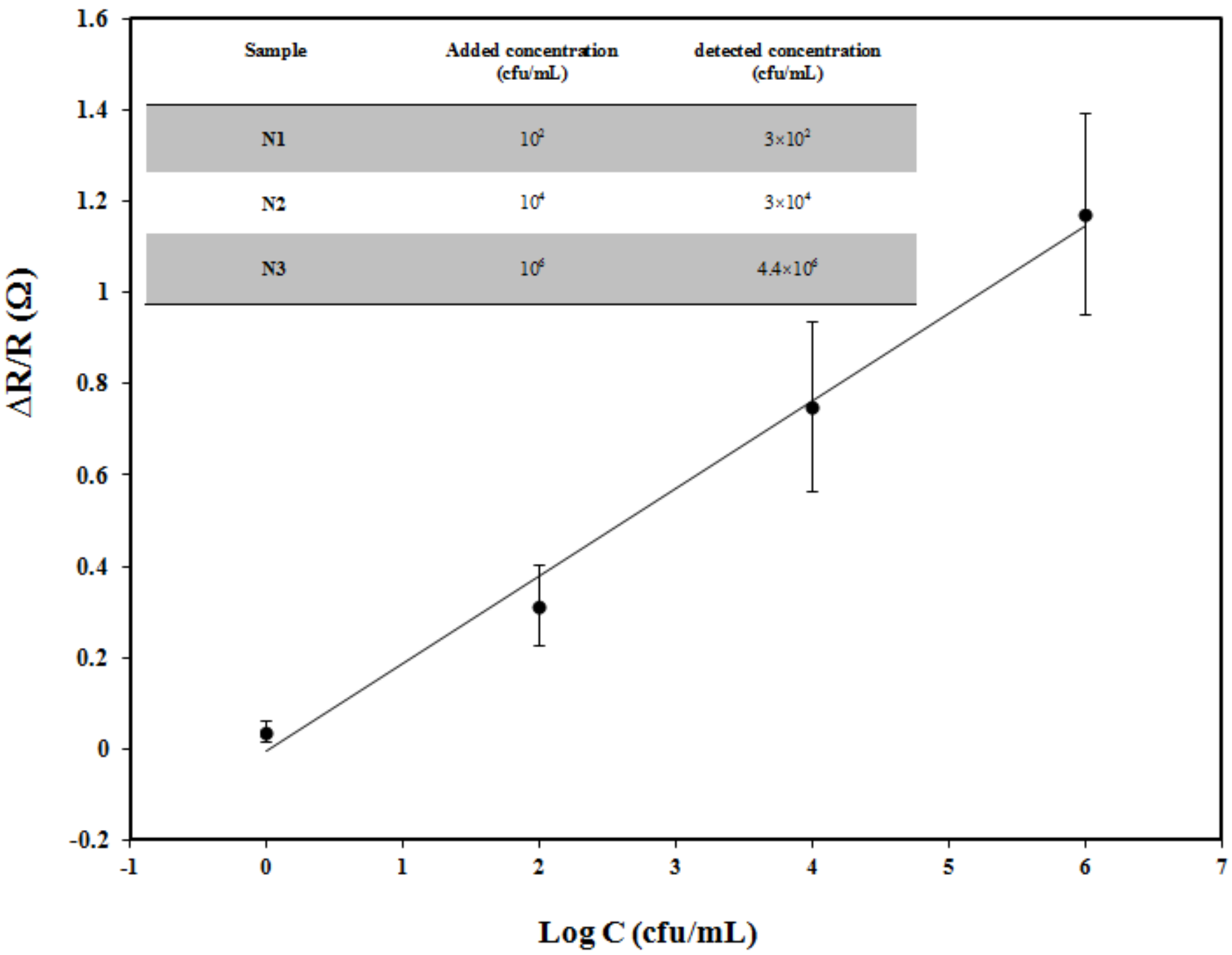

544

545

546

Fig. 5 